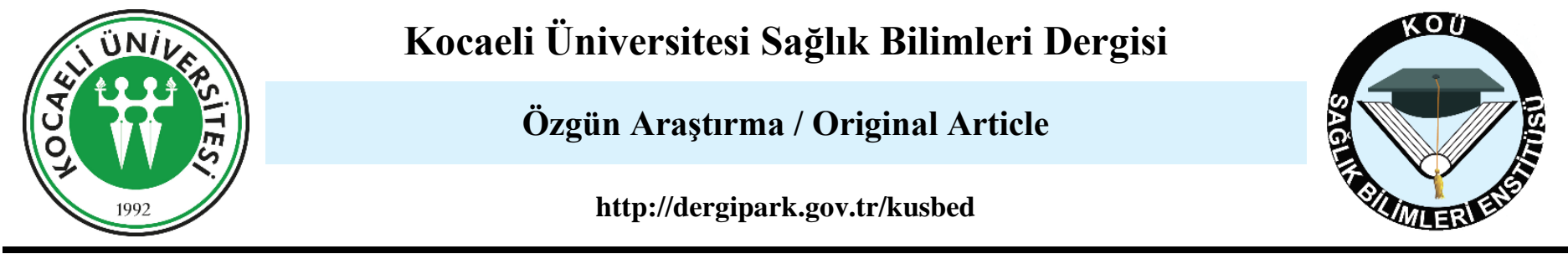

\title{
THE EVALUATION OF THE KNOWLEDGE AND BEHAVIOR OF CASES WITH SUSPICIOUS RABIES CONTACT ABOUT RABIES
}

\section{KUDUZ ŞÜPHELI TEMAS NEDENIYLE BAŞVURAN OLGULARIN KUDUZ HASTALIĞI HAKKINDAKI BILGII VE DAVRANIŞLARININ DE ĞERLENDIRILLMESI}

\author{
@(D) Osman Kurt ${ }^{* 1}$, (D) Ayşe Ferdane Oğuzöncül ${ }^{1}$ (D) Süleyman Erhan Deveci ${ }^{1}$
}

${ }^{1}$ Firat University, Faculty of Medicine, Department of Public Health. Elazıg, Turkey

ORCID iD: Osman Kurt: 0000-0003-4164-3611; Ayşe Ferdane Oğuzöncül: 0000-0002-9820-9720; Süleyman Erhan Deveci: 0000-0002-3041-2327

*Sorumlu Yazar / Corresponding Author: Osman Kurt e-posta / e-mail: drkurtosman @ gmail.com

\begin{tabular}{lll}
\hline Geliş Tarihi / Received: 14.05.2021 Kabul Tarihi / Accepted: 07.09.2021 & Yayım Tarihi / Published: 31.10 .2021
\end{tabular}

\begin{abstract}
Objective: The present study aimed to analyze the knowledge of rabies and behavior of the patients who were admitted due to contact with animals with rabies risk.

Methods: In the present cross-sectional and descriptive study, interviews were conducted with 108 patients who applied for rabies vaccine using a survey. The interview form included questions that aimed to determine the behavior and measure the knowledge of the cases after the suspicious contact.

Results: Among the study cases, $60.2 \%$ were male and the mean age was $33.80 \pm 17.64 .71 .0 \%$ of those who had pets with rabies transmission risk had vaccinated their pets. $67.6 \%$ of the patients applied to the nearest health institution after the animal contact, $13.9 \%$ did not care first but later applied to the hospital, $12.0 \%$ applied to the hospital because of fear, and 6.5\% applied to the hospital due to insistence of their friends. Also, $19.4 \%$ of the patients stated that they detained the animal for at least ten days after the contact. The score of the patients with rabies training was significantly higher than those without, the score of those who had domestic animals was significantly higher than those who had not, the score of those who vaccinated their pets was significantly higher than those who did not, and the score of those who vaccinated their pets with rabies transmission risk was significantly higher than those who did not vaccinate their pets $(p<0.05)$.

Conclusion: Patient behavior was problematic and the scores of educated individuals were higher. Education could improve the knowledge and awareness of rabies.
\end{abstract}

Keywords: Behavior, knowledge, rabies, vaccination.

\section{Öz}

Amaç: $\mathrm{Bu}$ çalışma kuduz riskli temas şikayetiyle hastaneye aşı için başvuran olguların kuduz hastalığı hakkındaki bilgi ve davranışlarını değerlendirmek amacıyla yapılmışıtır.

Yöntem: Kesitsel ve tanımlayıcı tipte olan bu çalışma kuduz aşısı yaptırmak için başvuran 108 hastaya anket aracılığı ile yüzyüze görüşülerek yapılmıştır. Ankette şüpheli temas sonrası yapılan davranış biçimi ve bilgi düzeyini ölçmeyi hedefleyen sorular bulunmaktadır.

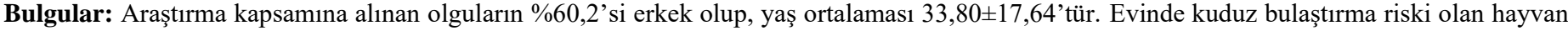
besleyenlerin \%71'i hayvanının aşısını yaptırmıştır. Hastaların \%67,6'sı hayvan teması sonrası en yakın sağlık kurumuna, \%13,9'u önceden önemsememiş olup sonradan hastaneye, \%12'si korktuğu için hastaneye ve \%6,5'i arkadaşlarının ısrarı ile hastaneye başvurmuştur. Yine hastaların $\% 19,4$ 'ü temas sonrası hayvanı en az on gün boyunca gözlemlemek için kapalı bir bölgede tuttuğunu belirtmiştir. Kuduz eğitimi alanların puanı almayanlardan, evde evcil hayvan besleyenlerin puanı beslemeyenlerden ve kuduz bulaştırma riskli evcil hayvan besleyenlerden aşılarını yaptıranların puanı yaptırmayanlardan anlamlı olarak fazla bulunmuştur $(p<0,05)$.

Sonuç: Hastaların davranışlarında eksiklikler olup, eğitim alanların bilgi puanı daha fazla bulunmuştur. Bireylerin eğitim almaları kuduz bilgisi ve farkındalığını arttırabilir.

Anahtar Kelimeler: Bă̆ışılklama, bilgi, davranış, kuduz. 


\section{Introduction}

Rabies is a zoonotic disease that leads to death due to encephalitis caused by Lyssavirus of the Rhabdoviridae family. While dogs are the most important transmitters of rabies in Turkey and several other areas, especially in developing countries, bats in the United States and foxes in Europe were reported as the most important transmitters. ${ }^{1,2}$ Rabies is indicated in more than 150 countries and 59000 individuals die annually from rabies. Dogs are the most prevalent transmitter with $91 \%$ of rabies suspected contacts worldwide. Dogs are followed by cats $(2 \%)$, other domestic animals (3\%), and bats (2\%). More than 15 million people receive post-exposure prophylaxis worldwide every year. Although rabies is a $100 \%$ preventable disease when postexposure prophylaxis is conducted, rabies-induced mortality is still observed in several countries. In Turkey, approximately 180 thousand contacts with rabies risk are reported, and an average of 1-2 rabies cases are recorded annually. .,3 $^{2,}$

The behaviors of those with a history of rabies risk contact at the time of contact are closely related to the patients' knowledge on this subject. It is very important to determine the level of knowledge of patients and people who have no contact history. In the studies, the characteristics of rabies risky contact cases in certain centers were examined in general. ${ }^{4,5}$ However, very few studies have been found in which the knowledge and behavior of those who applied to the hospital with a history of contact with rabies were evaluated. ${ }^{6}$

In this study, we aimed to evaluate the knowledge and behaviors of patients who applied to the hospital for vaccination with the complaint of rabies-risk contact.

\section{Methods}

The current cross-sectional and descriptive study was conducted in Firat University, Faculty of Medicine, Immunization Outpatient Clinic between March and September 2019. Ethics committee approval was obtained from Firat University, Non-Invasive Research Ethics Committee (No:050.01.04/311484), and administrative approval was obtained from Firat University, Faculty of Medicine Hospital administration.

The study was conducted on 108 patients who applied to the immunization outpatient clinic for rabies vaccine, volunteered, and were literate between the above-mentioned dates. Before the study, the participants were informed that the study data will not be used for non-scientific purposes, and the survey form questions were explained to the participants. The questionnaire was applied to the volunteering participants in the form of face to face interviews.

The survey questions were developed by the authors based on the literature., ${ }^{2,7}$ Questions covered both the knowledge and behavior of the participants. The highest possible knowledge score was 16 in the survey.

\section{Statistical analysis}

The study data were analyzed with statistics software. In statistical analysis, percentage, mean, t-test, and One-Way ANOVA tests were used based on the variable properties, and the Tukey test was employed to determine the group of origin for statistical significance. Means and standard deviations (mean $\pm \mathrm{SD}$ ) are presented, and $p<0.05$ was accepted as the statistical significance level.

\section{Results}

In the study, $60.2 \%$ of the cases were male, $39.8 \%$ were female, and the mean subject age was $33.80 \pm 17.64$ (min: 13, max: 80). The participant demographics are presented in Table 1.

Nineteen (17.6\%) participants stated that they received training on rabies. $89.5 \%$ of those who received training reported that the training was adequate.

It was determined that the animal of contact was a cat in $56.5 \%$ of the cases. It was observed that $16(14.8 \%)$ of these animals were the pets of the patients, $24(22.2 \%)$ were pets of others, and $68(63 \%)$ were stray animals (Table 2$)$.

Table 1. Participant demographics

\begin{tabular}{|c|c|c|c|}
\hline & & $\mathbf{n}$ & $\%$ \\
\hline \multirow{2}{*}{ Gender } & Male & 65 & 60.2 \\
\hline & Female & 43 & 39.8 \\
\hline \multirow{4}{*}{ Age } & 18 and younger & 16 & 14.8 \\
\hline & $19-29$ & 51 & 47.2 \\
\hline & $30-39$ & 5 & 4.6 \\
\hline & 40 and older & 36 & 33.4 \\
\hline \multirow{2}{*}{ Marital Status } & Married & 42 & 38.9 \\
\hline & Unmarried & 66 & 61.1 \\
\hline \multirow{2}{*}{ Residence } & Village/District & 23 & 21.3 \\
\hline & City & 85 & 78.7 \\
\hline \multirow{3}{*}{ Education Level } & Primary School or under & 29 & 26.9 \\
\hline & Middle/High School & 43 & 39.8 \\
\hline & College & 36 & 33.3 \\
\hline
\end{tabular}


Table 2. Rabies contact details and domestic animal ownership

\begin{tabular}{llll}
\hline & & $\mathbf{n}$ & $\mathbf{\%}$ \\
\hline The species of the animal of contact & Dog & 47 & 43.5 \\
\hline Type of contact & Cat & 61 & 56.5 \\
\hline Ownership of the animal of contact & Bite & 64 & 59.3 \\
& Claw & 44 & 40.7 \\
\hline \multirow{2}{*}{ Vaccination of the animal of contact } & Owned & 40 & 37.0 \\
& Stray & 68 & 63.0 \\
\hline & Vaccinated & 17.7 \\
The region of contact & Unvaccinated & 91 & 84.3 \\
\hline \multirow{2}{*}{ Domestic animal ownership } & Upper Extremity & 80 & 74.1 \\
& Lower Extremity & 26 & 24.1 \\
The species of the domestic animal & Breast & 0.9 \\
& Face and Neck & 1 & 0.9 \\
\hline Vaccination status of the domestic animal with rabies & Vaccinated & 41 & 38.0 \\
transmission potential & Yes & 67 & 62.0 \\
\hline
\end{tabular}

Among the patients, $35.2 \%$ applied to the outpatient clinic for the second dose of rabies vaccine, $38.9 \%$ applied for the third dose, $16.7 \%$ applied for the fourth dose, and $9.3 \%$ applied for the fifth dose.

Of the cases $63.9 \%$ answered the open-ended question "What are your suggestions for rabies prevention?" $63.8 \%$ of the responses were as "regular vaccinations" and of $36.2 \%$ were as "staying away from suspicious animals."

The participants were asked a multiple-choice question where more than one choice could be selected: "How did you clean the area of animal contact?" $63.9 \%$ of the cases cleaned the contact area with soap and water. $14.8 \%$ cleaned it with alcohol, $19.4 \%$ cleaned it with batticon, $3.7 \%$ cleaned it with hydrogen peroxide, $5.6 \%$ cleaned it by draining blood, $0.9 \%$ cleaned it with lemon juice, $0.9 \%$ cleaned it with saline solution, and $0.9 \%$ cleaned it with pomade. $18.5 \%$ of the participants never cleaned the area. The patient behaviors after contact are presented in Table 3.

Among the patients, $102(94.4 \%)$ stated that rabies is a fatal disease. Also, 105 (97.2\%) patients stated that rabies is transmitted by the bite or claw of an animal with rabies suspicion, $71(65.7 \%)$ stated that it is transmitted by the saliva of an animal on wounded skin, and $37(34.3 \%)$ stated that it is transmitted by the consumption of the raw meat of animals with rabies suspicion.

Ninety-three $(86.1 \%)$ participants stated that the rabid animal was aggressive, $39(36.1 \%)$ stated that it was with poor appetite, $41(38.0 \%)$ stated that it was erratic, and $85(78.7 \%)$ stated that it drooled excessively. The patient responses to other questions are presented in Table 4.

Table 3. Patient Behavior after Contact

\begin{tabular}{|c|c|c|c|}
\hline & & $\mathbf{n}$ & $\%$ \\
\hline \multirow{4}{*}{ Self-care after animal contact } & I applied to the nearest hospital & 73 & 67.6 \\
\hline & I applied to the hospital after my friends insisted & 7 & 6.5 \\
\hline & I applied to the hospital because I was scared & 13 & 12.0 \\
\hline & First, I did not care, but then I applied to the hospital & 15 & 13.9 \\
\hline \multirow{3}{*}{ Animal-care after the contact } & $\begin{array}{l}\text { I detained the animal in a closed environment for observation for } \\
10 \text { days }\end{array}$ & 21 & 19.4 \\
\hline & I tried to learn whether the animal was vaccinated for rabies & 22 & 20.4 \\
\hline & The animal ran away & 65 & 60.2 \\
\hline \multirow{5}{*}{ Time of hospital application } & $0-12$ days & 94 & 87.0 \\
\hline & $12-24$ & 9 & 8.3 \\
\hline & $24-48$ & 2 & 1.9 \\
\hline & $48-72$ & 1 & 0.9 \\
\hline & 72 days or over & 2 & 1.9 \\
\hline
\end{tabular}


Table 4. Patient Knowledge on Rabies

\begin{tabular}{|c|c|c|c|}
\hline & & $\mathbf{n}$ & $\%$ \\
\hline \multirow{3}{*}{ Can rabies be transmitted by humans? } & Yes & 60 & 55.6 \\
\hline & No & 26 & 24.1 \\
\hline & I do not know & 22 & 20.4 \\
\hline \multirow{3}{*}{$\begin{array}{l}\text { Can pregnant women receive the rabies } \\
\text { vaccine? }\end{array}$} & Yes & 20 & 18.5 \\
\hline & No & 31 & 28.7 \\
\hline & I do not know & 57 & 52.8 \\
\hline \multirow{3}{*}{$\begin{array}{l}\text { Can the vaccine protect individuals from } \\
\text { rabies? }\end{array}$} & Yes & 102 & 94.4 \\
\hline & No & 2 & 1.9 \\
\hline & I do not know & 4 & 3.7 \\
\hline \multirow{3}{*}{ Can rabies be treated? } & Yes & 73 & 67.6 \\
\hline & No & 28 & 25.9 \\
\hline & I do not know & 7 & 6.5 \\
\hline \multirow{5}{*}{$\begin{array}{l}\text { Which body part is more dangerous when } \\
\text { bitten? }\end{array}$} & Head and Neck & 77 & 71.3 \\
\hline & Arm and Hand & 6 & 5.6 \\
\hline & Abdomen and Torso & 7 & 6.5 \\
\hline & Feet and Legs & 1 & 0.9 \\
\hline & I do not know & 17 & 15.7 \\
\hline
\end{tabular}

The vast majority of those who applied to the nearest health facility after contact with suspicious animals were urban residents and the difference between this group and others was statistically significant $(p=0.003)$. There was a significant correlation between cleaning the wound area after contact with a suspicious animal and education favoring the educated individuals $(p=0.021)$.

The mean knowledge score of the patients on rabies was $10.51 \pm 1.73$ (min: 6, max: 14). There was no statistically significant difference between the knowledge scores based on gender and place of residence. There was a statistical difference between the education level and the mean knowledge score, and the difference was mainly between the scores of primary school graduates and illiterate group and the college graduates. The scores of patients with rabies training were significantly higher than those who did not, the scores of those with domestic animals were significantly higher than those without, and the scores of those who owned pets with rabies transmission risk were significantly higher than those who did not, and the scores of those who had their pets vaccinated were significantly higher than those who did not (Table 5).

Table 5. Comparison of the knowledge scores of the patients based on demographics, previous rabies training, and pet ownership

\begin{tabular}{|c|c|c|c|c|}
\hline & & $\mathbf{n}$ & Mean \pm SS & $p$ \\
\hline \multirow{2}{*}{ Gender } & Male & 65 & $10.55 \pm 1.72$ & \multirow{2}{*}{0.745} \\
\hline & Female & 43 & $10.44 \pm 1.77$ & \\
\hline \multirow{2}{*}{ Residence } & Village/District & 23 & $10.65 \pm 1.33$ & \multirow{2}{*}{0.659} \\
\hline & City & 85 & $10.47 \pm 1.83$ & \\
\hline \multirow{3}{*}{ Education Level } & Primary School or lower & 29 & $9.97 \pm 1.80^{\mathrm{a}}$ & \multirow{3}{*}{0.023} \\
\hline & Middle/High School & 43 & $10.37 \pm 1.74^{\mathrm{a}, \mathrm{b}}$ & \\
\hline & College & 36 & $11.11 \pm 1.52^{\mathrm{b}}$ & \\
\hline \multirow{2}{*}{ Previous rabies training } & Yes & 19 & $12.32 \pm 1.11$ & \multirow{2}{*}{$<0.001$} \\
\hline & No & 89 & $10.12 \pm 1.60$ & \\
\hline \multirow{2}{*}{ Pet ownership } & Yes & 41 & $11.17 \pm 1.54$ & \multirow{2}{*}{0.002} \\
\hline & No & 67 & $10.10 \pm 1.73$ & \\
\hline \multirow{2}{*}{$\begin{array}{l}\text { Vaccination status of the } \\
\text { pet* }\end{array}$} & Yes & 22 & $11.45 \pm 1.71$ & \multirow{2}{*}{0.048} \\
\hline & No & 9 & $10.11 \pm 1.45$ & \\
\hline
\end{tabular}

*The pets with rabies transmission potential. ${ }^{\mathrm{a}, \mathrm{b}}$ The groups where the difference originated. 


\section{Discussion}

Rabies is a virulent zoonotic viral disease that could be transmitted by domestic and wild animals. ${ }^{2}$ In Turkey, it is known that 82,000 people apply to health institutions every year due to animal bites. $95 \%$ of these bite cases are vaccinated. ${ }^{8}$

Rabies is a risk factor for both males and females. However, it is more common among men. ${ }^{9}$ In a study conducted by Akel Taşdemir et al., it was determined that males applied to the hospitals more than females. ${ }^{8}$ Similarly, in a study by Cesur and Olgun, the number of male hospital applicants was higher than female applicants. ${ }^{6}$ In the present study, more men applied to the hospital. The reason for the high number of risky contacts in males could be due to the fact that males spend more time outdoors.

Cleaning the wound with soap and water as soon as possible is a very effective protection method. In a study by Cesur and Olgun, most patients stated that they cleaned the wound with water and soap, and $15.4 \%$ stated that they did not. Similarly, in the study by Dodet et al., water and soap were used to clean the wound. ${ }^{10}$ In the present study, more than half of the patients stated that they cleaned the contact area with water and soap, while $28.5 \%$ did not clean the wound at all.

Being bitten by an infected animal is the primary means of transmission of the rabies virus. Furthermore, the infected animal could transmit the virus by clawing, through injured skin, and direct contact of the skin and the mucosa with animal saliva. More than half of the cases with rabies risk were due to animal bites. ${ }^{11}$ Tok et al. ${ }^{12}$ reported that biting was observed in $64 \%$ of the cases and clawing was observed in $31.9 \%$ of the cases. In the present study, biting was observed in $59.3 \%$ and scratching in $47.7 \%$ of the cases, and the present study findings were consistent with previous reports.

Cesur and Olgun reported that the aggressive animal was domestic in $29.0 \%$ of the cases. ${ }^{6}$ In the present study, it was determined that a domestic animal was the cause only in $37 \%$ of the cases. Since the measures to control stray animals are inadequate, the risk of contact between these animals and humans is high.

The wound area differs based on the species of the biting/clawing animal and the age of the victim. However, the most injured body parts were reported as the extremities. Ostanello et al. ${ }^{13}$ observed injuries in the head and neck region in $9.5 \%$ of the cases, in the lower extremities in $36.1 \%$ of the cases, and the upper extremities in $30.4 \%$ of the cases. Y1lmaz et al. ${ }^{11}$ reported that $5.8 \%$ of the cases were injured in the head-neck region, $42.3 \%$ in the upper extremities, and $44.9 \%$ in the lower extremities. Similar to the literature, $74.1 \%$ of the cases were contact upper extremities, $24.1 \%$ were in lower extremities, and $0.9 \%$ were in the face and neck region in the present study.

In Turkey, almost all rabies cases were induced by domestic animals, followed by dogs, cattle, cats, goats, sheep, and horses, respectively. ${ }^{2}$ In similar studies, Göktaş et al. ${ }^{14}$ and Özsoy et al. ${ }^{15}$ reported that dog attack ranked first and was twice as much as cat attacks. Contrary to the literature, cats ranked first, and dogs ranked second in the current study. This may be due to the high stray cat population in the region.

Local wound treatment aims to prevent virus infection. ${ }^{9}$ Therefore, those who are attacked by animals are expected to apply to a hospital as soon as possible. Most of the participants $(75.3 \%)$ in a study by Cesur and Olgun applied to the hospital in the first $12 \mathrm{hrs}^{6}{ }^{6}$ Similar rates were observed in the study by Göktaş et al. ${ }^{14}$. In the current study, the majority of the cases $(87.0 \%)$ were admitted to the hospital within 0-12 hrs. Although this could mean that people are sensitive about rabies, $10-15 \%$ of hospital admissions were over $12 \mathrm{hrs}$ after the animal contact.

Training on rabies and a high level of education are among the most important steps towards knowledge on rabies. Pirinçci et al. ${ }^{16}$ determined that the knowledge of those who were trained on rabies was significantly higher. Sambo et al. 17 reported that higher education levels led to higher success rates. In another study conducted in Ethiopia, it was reported that as the education level increased, the level of knowledge on rabies increased. ${ }^{18}$ Consistent with the literature, the knowledge levels of those with a high education level and those who have received training on rabies were high, indicating that education was associated with awareness in the present study.

In the study conducted by Sambo et al. ${ }^{17}$, the knowledge scores of those who have pets at home were significantly higher than those who did not have pets. In our study, it was determined that the knowledge scores of domestic animal owners and those who vaccinated their domestic animals with rabies risk were significantly higher. The high knowledge levels of the individuals with pets at home could be associated with the research they conducted about their pets and resulting awareness.

In conclusion, patients exhibited erratic behavior and the knowledge levels of educated individuals were higher. A high education level could be effective on high knowledge of rabies and awareness about the associated danger. It was observed that more than half of the contacts were with stray animals. The municipalities should take the necessary precautions to reduce the frequency of contact with animals with rabies risk.

\section{Declaration of Conflict of Interest}

Thereis no conflict of interest

\section{References}

1. WHO Expert Consultation on Rabies. Second report. World Health Organization technical report series 2013; 982:1-139.

2. T.C. Sağlık Bakanlığı. Kuduz Profilaksi Rehberi 2019.

3. World Health Organization. Weekly epidemiological record. WHO Geneva 2017; 92: 77-88.

4. Temiz H, Akkoç H. Diyarbakır Devlet Hastanesi Kuduz Aşı Merkezine Başvuran 809 Olgunun Değerlendirilmesi. Dicle Med J. 2008; 35(3): 181-184.

5. Balin ŞÖ, Denk A. Kuduz Riskli Temas Bildirimlerinin Değerlendirilmesi. Firat Tip Dergisi. 2016; 21(3): 141-144.

6. Cesur M, Olgun N. Kuduz Şüpheli Hayvan Saldırısı Şikayetiyle Hastaneye Başvuran Olguların Kuduz Hastalığı Hakkındaki Bilgi, Tutum ve Davanışları. AUHSJ. 2014;5:135140.

7. Laishram J, Chaudhuri S, Devi HS, Konjengbam S. Knowledge and Practice on Rabies in An Urban Community of Manıpur, India. J. Evolution Med. Dent. Sci. 2016; 37(5):2234-2237.

8. Akel Taşdemir R, Oğuzöncül AF, Pirinçci E. Bir İlçe Devlet Hastanesi Acil Servisine Kuduz Şüphesi ile Başvuran Olguların Değerlendirilmesi. Kocaeli Medical J. 2017; 6:6367.

9. T.C. Sağlık Bakanlığı - Zoonotik Hastalıklar Daire Başkanlığı. Zoonotik hastalıklar hizmet içi eğitim modülü (2011). (https://sbu.saglik.gov.tr/Ekutuphane/kitaplar/Zoonotik\%20H astaliklar\%20Katilimci\%20Kitabi.pdf) (Erişim tarihi: 14.05.2021).

10. Dodet B, Goswami A, Gunasekera A. Rabiesawareness in eigth Asian Countries. Vaccine. 2008; 26: 6344-6348. doi: 10.1016/j.vaccine.2008.09.003. 
11. Yılmaz F, Akbulut AS, Taş M, Kavalcı C, Arslan ED, Sönmez M. Evaluation of Cases with Rabies Risk Presenting to Emergency Department. JCAM. 2014; 5(1):8-11.

12. Tok D, Akçaer M, Coşkun Ö, Karakaş A, Çekli Y. Kuduz riskli temas nedeni ile bir aşı merkezine başvuran olguların değerlendirilmesi. TAF Preventive Medicine Bulletin. 2016; 15(3): 248-251.

13. Ostanello F, Gherardi A, Caprioli A, La Placa L, Passini A, Prosperi S. Incidence of injuries caused by dogs and cats treated in emergency departments in a major Italian city. EMJ. 2005. 22(4): 260-262. doi: 10.1136/emj.2004.014886.

14. Göktaş F, Ceren N, Karagül E, Çiçek G, Özyürek S. Kuduz aş1 merkezine başvuran 11017 olgunun değerlendirilmesi. Klimik Dergisi. 2002;15(1)12-15.

15. Özsoy M, Yakıştıran S, Özkan E. 2000 yılında kuduz aş1 merkezine başvuran hastaların değerlendirilmesi. THDBD. 2002;59:1-6.

16. Pirincci E, Kurt O, Oguzoncul AF, Deveci SE. Knowledge and behaviors of veterinary students about rabies: A descriptive study from Turkey. Niger J Clin Pract. 2020; 23: 1281-1288. doi: 10.4103/njcp.njcp_108_19.

17. Sambo M, Lembo T, Cleaveland $S$, et al. K. Knowledge, attitudes and practices (KAP) about rabies prevention and control: a community survey in Tanzania. PLoS Negl Trop Dis. 2014; 8(12): e3310. https://doi.org/10.1371/journal.pntd.0003310

18. Ali A, Ahmed EY, Sifer D. A study on knowledge, attitude and practice of rabies among residents in Addis Ababa, Ethiopia. Ethiop. Vet. J. 2013; 17(2): 19-35. doi: 10.4314/evj.v17i2.2 